\title{
Főderalígmus
}

\section{aus $\mathfrak{D}$ eltanjahauung}

Bon

Dr. Ëbgar $\mathfrak{3}$. Jung

Rechtżannalt in Mändjen

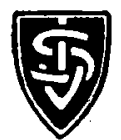

1931

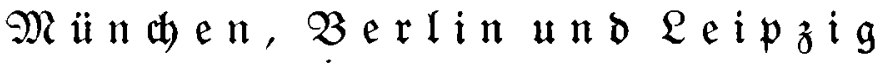

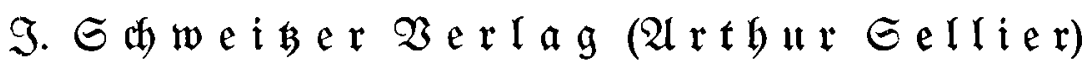


Druđ von Dr. \$. p. Datterer \& Cie., Sreiling=Mündien. 


\section{Snhalt:}

Seite

Einleitung . . . . . . . . . . . 5

Medhaniโher und organilder Staat . . . . . . . 9

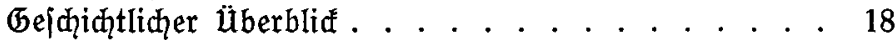

Der deutihe Reiḑsgedanfe . . . . . . . . . 23

Das Ganze und die đeile in iḩrem Derḩältnis zueinander 27

Die deutiche Gliederung 1871 und heute. . . . . . . 29

Der bedrängte §öderalismus . . . . . . . . . . 34

Der heutige Stand der Reid=Eänderfrage . . . . . 37

Reid und preuken ............ . 45

Derfáfiungsred̨tliđe Keugejtaitung . . . . . . . . 47

Zujtändigfeiten . . . . . . . . . . . 57

Sinanzausgleidh . . . . . . . . . . 63

Söderalismus in der Auß̈enpolitif . . . . . . . . . 68 
